\title{
Identification of anthropogenic influences on water quality of rivers in Taihu watershed
}

\author{
WANG Xiao-long $^{1,2}$, LU Yong-long ${ }^{1, *}$, HAN Jing-yi ${ }^{1,3}$, HE Gui-zhen $^{1,2}{ }^{\text {, WANG Tie-yu }}{ }^{1}$ \\ 1. State Key Laboratory of Urban and Regional Ecology, Research Center for Eco-Environmental Sciences, Chinese Academy of Sciences, Beijing \\ 100085, China.E-mail:wangjie78eo@yahoo.com.cn \\ 2. Graduate School of the Chinese Academy of Sciences, Beijing 100039, China \\ 3. Environmental Policy Group, Wageningen University, $6706 \mathrm{KN}$ Wageningen, The Netherlands
}

Received 20 August 2006; accepted 24 November 2006

\begin{abstract}
Surface water bodies are progressively subjected to stress as a result of anthropogenic activities. This study assessed and examined the impact of human activities on spatial variation in the water quality of 19 rivers in the Taihu watershed. Concentrations of physicochemical parameters of surface water quality were determined at the mouth of each river during the period of 2000-2004. Multivariate statistical techniques were applied to identify characteristics of the water quality in the studied rivers. The results showed that rivers strongly influenced by household wastewater have the highest concentrations of nutrients (TN and TP). Moreover, rivers in the vicinity of a metropolis presented low dissolved oxygen (DO) levels. However, organic-chemical pollution (petroleum and volatile phenolics) was identified with high localization. Two rivers influenced by sewage from industry and ships were distinguished from other rivers with high values of petroleum. The Taige channel, a river located in Changzhou City that is strongly influenced by wastewater from industry, was characterized with an extraordinarily high value of volatile phenolics. Rivers passing through countries, especially through hilly countries were characterized with high DO contents and low nutrient and organic-chemical pollution, suggesting that agriculture puts less pressure on water quality in adjacent rivers. Therefore, more effort should be made in controlling point pollution to restore water quality in rivers adjacent to cities.
\end{abstract}

Key words: water quality; anthropogenic activities; principal component analysis; cluster analysis; Taihu watershed

\section{Introduction}

Anthropogenic activities result in significantly decrease of surface water quality of aquatic systems in watersheds (May et al., 2006). Rivers in a watershed play a major role in assimilating or carrying off municipal and industrial wastewater and runoff from agricultural land. River inflows contribute main pollutants to most lakes in a watershed, thereby tending to induce serious ecological and sanitary problems (Gilbert and Wendy, 2003; Kunwar et al., 2005). On the other hand, rivers constitute the main water resources for domestic, industrial, and irrigation purposes in a watershed (Yu and Shang, 2003). Thus it is imperative to prevent and control river pollution and to have reliable information on the quality of water for effective management. Generally, water-related environmental quality is in bad condition due to a great deal of waste, excessive reclamation, over-fishing, and frequent petroleum spills (Lin and Han, 2001; Chen et al., 2003). For most watersheds with greatly varying topographical conditions, the water quality of rivers is characterized by

Project supported by the International Project between The Netherlands Royal Academy of Arts and Sciences and Chinese Academy of Sciences (No. 04CDP014) and the National Natural Science Foundation of China (No. 40471130).*Corresponding author. E-mail: yllu@ cashq.ac.cn. a high degree of heterogeneity in space and time, due to the variety of land cover around them. This often makes it difficult to identify water conditions and pollution sources, which is necessary for effective pollution control and water resource management (Kunwar et al., 2005).

Taihu watershed, one of the most developed regions in China, is in the lower reaches of the Yangtze River. The distribution of numerous rivers and lakes strongly benefits the high-speed development of the local society and economy. However, in recent years, because the rapid development of the local economy and subsequent intensive use of water resources, surface water pollution has become increasingly serious, restricting the sustainable development of the local economies (Jin, 2000; Li, et al., 2000). Considerable effort has been made to identify the sources and variations of pollutants in surface water. Several intensive studies focusing on specific aquatic systems provided good insight into the character of pollutant input from individual inflow rivers, as well as the further influence on the aquatic ecological system (Cai et al., 1997; Chen et al., 1997). However, to achieve sustainable management of the water quality at the watershed level, it is also necessary to identify and classify the difference of water quality in all principal rivers through long-term 
comprehensive investigation.

In this study, physico-chemical parameters of water quality in the 19 rivers form the principal river net in the Taihu watershed were determined monthly over a 5-year term. Multivariate statistical tools were used to evaluate the effects of human activities on the characteristics of water quality in these rivers. These tools were used widely to discern environmental problems and were proved useful to deal with complex environmental datasets (Lau and Lane, 2002; Bernard et al., 2004)). The goals of this paper are to delineate the characteristics of the water quality of main rivers around Taihu Lake and to identify anthropogenic influence on the variation of specific indictors of water quality within these rivers.

\section{Materials and methods}

\subsection{Study area}

The Taihu watershed includes parts of Jiangsu and Zhejiang Provinces and the Shanghai municipality. There are approximately 32 million inhabitants in the large drainage basin. This is one of the most developed areas in China. More than 200 rivers at different scales are distributed in the watershed, among which about 20 main rivers form the principal river net which contributes the most water and pollution input to Taihu Lake, the third largest freshwater lake in China (Li et al., 2000). These rivers, which belong to different municipalities, are subject to different anthropogenic activities due to their heterogeneity in land cover around them (Luo and Peng, 2005). The dominant pollution sources for each river are listed in Table 1.

\subsection{Sampling site and sample analysis}

Surface water $(0-0.5 \mathrm{~m})$ was collected monthly at the mouth of each river during 2000-2004 (Fig.1). The water samples were immediately preserved in $1 \mathrm{~L}$ polypropylene sampling bottles at $4^{\circ} \mathrm{C}$ in darkness and analyzed within

Table 1 Dominant pollution sources for rivers

\begin{tabular}{|c|c|c|c|}
\hline Code & River name & $\begin{array}{l}\text { Predominant pollution } \\
\text { source }\end{array}$ & Municipality \\
\hline 1 & Liangxi River & Household & Wuxi City \\
\hline 2 & Zhihu River & Household/Industry & \\
\hline 3 & Xiaoxi River & Household/Tourism & \\
\hline 4 & Wujin River & Industry/Ship/Household & Changzhou City \\
\hline 5 & Taige Canal & Household /Industry & \\
\hline 6 & Caoqiao River & Industry/Ship & \\
\hline 7 & South Taige Canal & Household/Ship & Yixing City \\
\hline 8 & Shedu River & Household/Agricultural & \\
\hline 9 & Guandu River & Agricultural & \\
\hline 10 & Dapu River & Agricultural & \\
\hline 11 & Wuxi River & Agricultural & \\
\hline 12 & Dagang River & Agricultural & \\
\hline 13 & Taipu River & Agricultural & Suzhou City \\
\hline 14 & Wusong River & Aquaculture/Agricultural & \\
\hline 15 & Sudong River & Aquaculture/Agricultural & \\
\hline 16 & Xu River & Agricultural/Aquaculture & \\
\hline 17 & Muguang River & Agricultural & \\
\hline 18 & Xuguang River & Agricultural & \\
\hline 19 & Wangyu River & Agricultural & \\
\hline
\end{tabular}

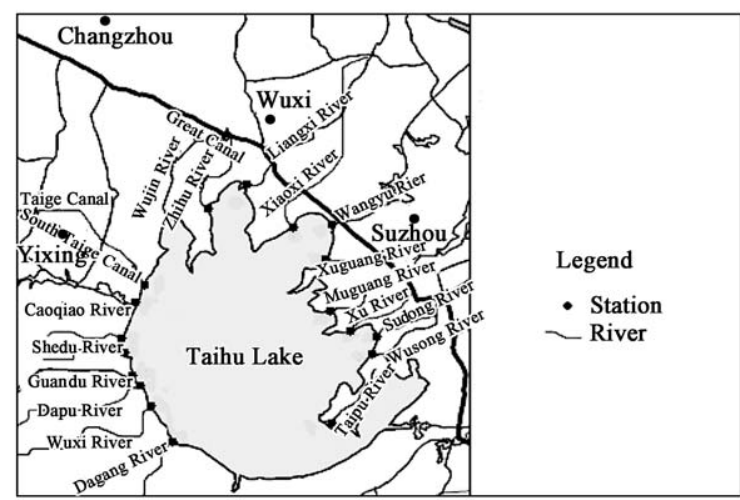

Fig. 1 Study area and sampling stations of rivers in the Taihu watershed.

$48 \mathrm{~h}$. The parameters of water quality included suspended solids (SS), conductivity (Cond), dissolved oxygen (DO), $\mathrm{pH}$, chemical oxygen demand (COD), biologic oxygen demand (BOD), total nitrogen (TN), ammonium nitrogen $\left(\mathrm{NH}_{4}-\mathrm{N}\right)$, total phosphates (TP), petroleum (Petro) and volatile phenolics (V-phen). The $\mathrm{pH}$, conductivity, and DO were determined directly at each sampling site. The conductivity was measured with YSI meter Model 33 (YSI, USA), the $\mathrm{pH}$ was measured by a $\mathrm{pH}$ meter Beckman Model F8 253 (Beckman, USA), and the DO was measured by a YSI oxygen meter Model 57 (YSI, USA). The SS, COD, BOD, TN, $\mathrm{NH}_{4}-\mathrm{N}$, and TP were determined using standard methods (Jin, 1998). Petro was measured using Infrared Spectrophotometry, and V-phen was measured using Flow Injection-Spectrophotometry (Jin, 1998; Liu, 2005).

\subsection{Data preparation and analysis}

The average data of each river, based on pooled samples in the study period, were determined. The structure of the water quality indicator variability of the data was explored using a multivariate statistical approach. Principal component analysis (PCA) and cluster analysis (CA) were employed to sort the variables of water quality indicators and sampling stations, respectively. Non-normality of the data was treated by taking a logarithm or square root, whenever appropriate (Ludwig and Reynolds, 1988). PCA was useful for considering several related random environmental variables simultaneously, and thus for identifying a new, small set of uncorrelated variables that accounted for a large proportion of the total variance in the original variables (Lau and Lane, 2002). In order to classify the variations of water quality indicators, eleven indicators, including $\mathrm{pH}, \mathrm{DO}, \mathrm{SS}$, Cond, COD, BOD, TN, $\mathrm{NH}_{4}-\mathrm{N}, \mathrm{TP}$, Petro and V-phen were used for PCA. A correlation matrix of these variables was computed, and factor loading was defined to explore the nature of variation and principal patterns amongst them (Reyment and Joreskog, 1993). Any factor with an eigenvalue greater than unity (eigenvalue $>1$ ) was considered significant. To evaluate the influence of anthropogenic activities on water quality in the studied rivers, multivariate cluster analysis (Q-cluster analysis) was performed using the square of the mean Euclidian distance matrix and the correlation matrix, based on each significant principal factor obtained by PCA respectively. 
All statistical analyses were conducted using the statistical software package SPSS 11.0, and significance was determined at the $95 \%$ confidence level.

\section{Results and discussion}

\subsection{Concentrations of physico-chemical parameters of water quality of rivers in the Taihu watershed}

\subsubsection{Physical parameters}

Table 2 shows the average values of 11 parameters of water quality in the 19 rivers. Rivers influenced by urbanization, namely affected by sewages from industry and household (Liangxi River, Zhihu River, Wujin River, Taige Canal and Caoqiao River), yielded relatively high SS values, while lower SS values were found in rivers influenced by agricultural or/and aquaculture (Dagang River, Sudong River, $\mathrm{Xu}$ River, Muguang River and Xuguang River). The lowest DO level $(2.70 \mathrm{mg} / \mathrm{L})$ was found in the Liangxi River; and the DO values in the Wujin River, Taige Canal, and Caoqiao River were also significantly lower than the other rivers except for the Liangxi River, in the range from $3.14-3.36 \mathrm{mg} / \mathrm{L}$. This suggests that the discharge of industry and domestic wastewater induced serious organic pollution in these rivers, since the decrease of DO was mainly caused by the decomposition of organic compounds (Boyle and Fraleigh, 2003). Moreover, extremely low DO content usually indicates the degradation of an aquatic system (Cai et al., 1997; Zheng et al., 2001). The highest DO contents were found in the Dapu River $(8.95 \mathrm{mg} / \mathrm{L})$ and the Taipu River $(9.56 \mathrm{mg} / \mathrm{L})$. Average conductivity values of all studied rivers were in the range of $29.38(\mu \mathrm{S} / \mathrm{cm})$ to $72.75(\mu \mathrm{S} / \mathrm{cm})$, among which the Liangxi River, Zhihu River, Wujin River and Taige Canal showed higher values of conductivity than others. This can be ascribed to the discharge of industrial and domestic sewage, which put large amounts of alkaline ions into the river system, since conductivity depends mostly on ion concentration in surface water (Bernard et al., 2004).

\subsubsection{Chemical parameters}

The $\mathrm{pH}$ values of the 19 rivers in Table 1 showed less variation, ranging from 7.22 to 7.72. Relatively high COD contents were found in the Liangxi River, Wujin River, Taige Canal and Zhihu River; the BOD contents showed a similar trend. The Liangxi River showed the highest

Table 2 Concentrations of physico-chemical parameters of water quality of rivers in Taihu watershed

\begin{tabular}{|c|c|c|c|c|c|c|c|c|c|c|c|}
\hline River & $\mathrm{pH}$ & $\begin{array}{c}\mathrm{SS} \\
(\mathrm{mg} / \mathrm{L})\end{array}$ & $\begin{array}{c}\text { DO } \\
(\mathrm{mg} / \mathrm{L})\end{array}$ & $\begin{array}{l}\text { COD } \\
(\mathrm{mg} / \mathrm{L})\end{array}$ & $\begin{array}{l}\text { BOD } \\
(\mathrm{mg} / \mathrm{L})\end{array}$ & $\begin{array}{l}\mathrm{NH}_{4}-\mathrm{N} \\
(\mathrm{mg} / \mathrm{L})\end{array}$ & $\begin{array}{c}\mathrm{TN} \\
(\mathrm{mg} / \mathrm{L})\end{array}$ & $\begin{array}{c}\mathrm{TP} \\
(\mathrm{mg} / \mathrm{L})\end{array}$ & $\begin{array}{l}\text { Petro } \\
(\mathrm{mg} / \mathrm{L})\end{array}$ & $\begin{array}{l}\text { V-phen } \\
(\mathrm{mg} / \mathrm{L})\end{array}$ & $\begin{array}{l}\text { Cond } \\
(\mu \mathrm{S} / \mathrm{cm})\end{array}$ \\
\hline Liangxi River & $\begin{array}{l}7.22 \\
(0.32)^{\mathrm{a}}\end{array}$ & $\begin{array}{l}58.56 \\
(19.55)\end{array}$ & $\begin{array}{l}2.70 \\
(1.69)\end{array}$ & $\begin{array}{l}8.31 \\
(2.01)\end{array}$ & $\begin{array}{l}7.53 \\
(2.73)\end{array}$ & $\begin{array}{l}5.30 \\
(2.22)\end{array}$ & $\begin{array}{l}8.82 \\
(2.76)\end{array}$ & $\begin{array}{l}0.311 \\
(0.152)\end{array}$ & $\begin{array}{l}0.226 \\
(0.224)\end{array}$ & $\begin{array}{l}0.013 \\
(0.011)\end{array}$ & $\begin{array}{l}7156 \\
(19.66)\end{array}$ \\
\hline Zhihu River & $\begin{array}{l}7.51 \\
(0.24)\end{array}$ & $\begin{array}{l}59.11 \\
(19.69)\end{array}$ & $\begin{array}{l}4.38 \\
(2.27)\end{array}$ & $\begin{array}{l}7.76 \\
(1.67)\end{array}$ & $\begin{array}{l}5.39 \\
(1.93)\end{array}$ & $\begin{array}{l}3.48 \\
(2.52)\end{array}$ & $\begin{array}{l}6.51 \\
(2.88)\end{array}$ & $\begin{array}{l}0.215 \\
(0.125)\end{array}$ & $\begin{array}{l}0.342 \\
(0.142)\end{array}$ & $\begin{array}{l}0.009 \\
(0.004)\end{array}$ & $\begin{array}{l}76.75 \\
(19.28)\end{array}$ \\
\hline Xiaoxi River & $\begin{array}{l}7.54 \\
(0.43)\end{array}$ & $\begin{array}{l}39.89 \\
(10.47)\end{array}$ & $\begin{array}{l}4.76 \\
(3.82)\end{array}$ & $\begin{array}{l}6.68 \\
(2.05)\end{array}$ & $\begin{array}{l}6.30 \\
(2.83)\end{array}$ & $\begin{array}{l}4.11 \\
(2.75)\end{array}$ & $\begin{array}{l}5.68 \\
(2.75)\end{array}$ & $\begin{array}{l}0.238 \\
(0.142)\end{array}$ & $\begin{array}{l}0.323 \\
(0.172)\end{array}$ & $\begin{array}{l}0.004 \\
(0.003)\end{array}$ & $\begin{array}{l}56.04 \\
(17.23)\end{array}$ \\
\hline Wujin River & $\begin{array}{l}7.37 \\
(0.44)\end{array}$ & $\begin{array}{l}64.75 \\
(10.84)\end{array}$ & $\begin{array}{l}3.14 \\
(1.81)\end{array}$ & $\begin{array}{l}7.24 \\
(1.80)\end{array}$ & $\begin{array}{l}5.45 \\
(1.23)\end{array}$ & $\begin{array}{l}4.82 \\
(3.11)\end{array}$ & $\begin{array}{l}6.64 \\
(3.45)\end{array}$ & $\begin{array}{l}0.284 \\
(0.095)\end{array}$ & $\begin{array}{l}0.716 \\
(0.031)\end{array}$ & $\begin{array}{l}0.008 \\
(0.005)\end{array}$ & $\begin{array}{l}69.64 \\
(18.19)\end{array}$ \\
\hline Taige Canal & $\begin{array}{l}7.34 \\
(0.23)\end{array}$ & $\begin{array}{l}58.97 \\
(39.14)\end{array}$ & $\begin{array}{l}3.14 \\
(2.13)\end{array}$ & $\begin{array}{l}7.26 \\
(2.34)\end{array}$ & $\begin{array}{l}7.97 \\
(2.44)\end{array}$ & $\begin{array}{l}3.49 \\
(2.28)\end{array}$ & $\begin{array}{l}4.85 \\
(2.76)\end{array}$ & $\begin{array}{l}0.287 \\
(0.184)\end{array}$ & $\begin{array}{l}0.289 \\
(0.069)\end{array}$ & $\begin{array}{l}0.069 \\
(0.045)\end{array}$ & $\begin{array}{l}67.46 \\
(22.14)\end{array}$ \\
\hline Caoqiao River & $\begin{array}{l}7.38 \\
(0.26)\end{array}$ & $\begin{array}{l}62.69 \\
(17.52)\end{array}$ & $\begin{array}{l}3.36 \\
(1.49)\end{array}$ & $\begin{array}{l}6.64 \\
(1.65)\end{array}$ & $\begin{array}{l}3.23 \\
(0.93)\end{array}$ & $\begin{array}{l}2.26 \\
(1.19)\end{array}$ & $\begin{array}{l}3.71 \\
(2.01)\end{array}$ & $\begin{array}{l}0.230 \\
(0.056)\end{array}$ & $\begin{array}{l}0.812 \\
(0.363)\end{array}$ & $\begin{array}{l}0.019 \\
(0.021)\end{array}$ & $\begin{array}{l}59.81 \\
(21.04)\end{array}$ \\
\hline South-Taige Canal & $\begin{array}{l}7.39 \\
(0.23)\end{array}$ & $\begin{array}{l}39.08 \\
(14.18)\end{array}$ & $\begin{array}{l}4.43 \\
(2.29)\end{array}$ & $\begin{array}{l}6.62 \\
(1.53)\end{array}$ & $\begin{array}{l}6.52 \\
(2.21)\end{array}$ & $\begin{array}{l}2.14 \\
(1.55)\end{array}$ & $\begin{array}{l}4.05 \\
(2.04)\end{array}$ & $\begin{array}{l}0.191 \\
(0.152)\end{array}$ & $\begin{array}{l}0.165 \\
(0.103)\end{array}$ & $\begin{array}{l}0.009 \\
(0.011)\end{array}$ & $\begin{array}{l}54.41 \\
(15.89)\end{array}$ \\
\hline Shedu River & $\begin{array}{l}7.47 \\
(0.27)\end{array}$ & $\begin{array}{l}42.04 \\
(17.11)\end{array}$ & $\begin{array}{l}4.89 \\
(2.39)\end{array}$ & $\begin{array}{l}6.66 \\
(1.52)\end{array}$ & $\begin{array}{l}6.84 \\
(3.70)\end{array}$ & $\begin{array}{l}4.66 \\
(3.08)\end{array}$ & $\begin{array}{l}7.38 \\
(3.94)\end{array}$ & $\begin{array}{l}0.168 \\
(0.147)\end{array}$ & $\begin{array}{l}0.132 \\
(0.069)\end{array}$ & $\begin{array}{l}0.004 \\
(0.001)\end{array}$ & $\begin{array}{l}54.52 \\
(12.06)\end{array}$ \\
\hline Guandu River & $\begin{array}{l}7.46 \\
(0.23)\end{array}$ & $\begin{array}{l}39.54 \\
(20.69)\end{array}$ & $\begin{array}{l}5.25 \\
(1.91)\end{array}$ & $\begin{array}{l}6.28 \\
(1.25)\end{array}$ & $\begin{array}{l}6.66 \\
(2.96)\end{array}$ & $\begin{array}{l}2.18 \\
(1.72)\end{array}$ & $\begin{array}{l}4.98 \\
(1.97)\end{array}$ & $\begin{array}{l}0.124 \\
(0.098)\end{array}$ & $\begin{array}{l}0.157 \\
(0.070)\end{array}$ & $\begin{array}{l}0.005 \\
(0.009)\end{array}$ & $\begin{array}{l}49.68 \\
(11.91)\end{array}$ \\
\hline Dapu River & $\begin{array}{l}7.57 \\
(0.39)\end{array}$ & $\begin{array}{l}42.75 \\
(20.57)\end{array}$ & $\begin{array}{l}8.95 \\
(2.22)\end{array}$ & $\begin{array}{l}5.21 \\
(0.71)\end{array}$ & $\begin{array}{l}4.89 \\
(1.96)\end{array}$ & $\begin{array}{l}0.68 \\
(0.48)\end{array}$ & $\begin{array}{l}3.32 \\
(1.41)\end{array}$ & $\begin{array}{l}0.119 \\
(0.106)\end{array}$ & $\begin{array}{l}0.168 \\
(0.182)\end{array}$ & $\begin{array}{l}0.011 \\
(0.007)\end{array}$ & $\begin{array}{l}48.03 \\
(11.92)\end{array}$ \\
\hline Wuxi River & $\begin{array}{l}7.25 \\
(0.21)\end{array}$ & $\begin{array}{l}31.08 \\
(11.34)\end{array}$ & $\begin{array}{l}5.72 \\
(2.51)\end{array}$ & $\begin{array}{l}4.62 \\
(0.88)\end{array}$ & $\begin{array}{l}4.12 \\
(1.66)\end{array}$ & $\begin{array}{l}0.74 \\
(0.53)\end{array}$ & $\begin{array}{l}3.17 \\
(1.21)\end{array}$ & $\begin{array}{l}0.113 \\
(0.107)\end{array}$ & $\begin{array}{l}0.157 \\
(0.118)\end{array}$ & $\begin{array}{l}0.009 \\
(0.011)\end{array}$ & $\begin{array}{l}44.19 \\
(9.35)\end{array}$ \\
\hline Dagang River & $\begin{array}{l}7.25 \\
(0.35)\end{array}$ & $\begin{array}{l}17.19 \\
(7.38)\end{array}$ & $\begin{array}{l}5.82 \\
(3.37)\end{array}$ & $\begin{array}{l}3.39 \\
(1.82)\end{array}$ & $\begin{array}{l}3.39 \\
(2.38)\end{array}$ & $\begin{array}{l}0.58 \\
(0.74)\end{array}$ & $\begin{array}{l}2.82 \\
(1.02)\end{array}$ & $\begin{array}{l}0.056 \\
(0.072)\end{array}$ & $\begin{array}{l}0.113 \\
(0.084)\end{array}$ & $\begin{array}{l}0.012 \\
(0.089)\end{array}$ & $\begin{array}{l}29.38 \\
(21.96)\end{array}$ \\
\hline Taipu River & $\begin{array}{l}7.72 \\
(0.47)\end{array}$ & $\begin{array}{l}26.33 \\
(11.52)\end{array}$ & $\begin{array}{l}9.56 \\
(2.19)\end{array}$ & $\begin{array}{l}3.71 \\
(0.53)\end{array}$ & $\begin{array}{l}1.51 \\
(0.84)\end{array}$ & $\begin{array}{l}0.23 \\
(0.15)\end{array}$ & $\begin{array}{l}0.54 \\
(0.20)\end{array}$ & $\begin{array}{l}0.055 \\
(0.051)\end{array}$ & $\begin{array}{l}0.039 \\
(0.022)\end{array}$ & $\begin{array}{l}0.003 \\
(0.002)\end{array}$ & $\begin{array}{l}38.46 \\
(7.75)\end{array}$ \\
\hline Wusong River & $\begin{array}{l}7.35 \\
(0.30)\end{array}$ & $\begin{array}{l}33.92 \\
(16.70)\end{array}$ & $\begin{array}{l}5.64 \\
(2.08)\end{array}$ & $\begin{array}{l}6.09 \\
(1.64)\end{array}$ & $\begin{array}{l}4.12 \\
(2.37)\end{array}$ & $\begin{array}{l}2.10 \\
(1.93)\end{array}$ & $\begin{array}{l}2.89 \\
(2.28)\end{array}$ & $\begin{array}{l}0.233 \\
(0.223)\end{array}$ & $\begin{array}{l}0.041 \\
(0.045)\end{array}$ & $\begin{array}{l}0.006 \\
(0.004)\end{array}$ & $\begin{array}{l}59.41 \\
(17.36)\end{array}$ \\
\hline Sudong River & $\begin{array}{l}7.43 \\
(0.34)\end{array}$ & $\begin{array}{l}20.67 \\
(7.35)\end{array}$ & $\begin{array}{l}5.53 \\
(2.88)\end{array}$ & $\begin{array}{l}5.77 \\
(1.25)\end{array}$ & $\begin{array}{l}3.65 \\
(1.25)\end{array}$ & $\begin{array}{l}1.19 \\
(1.25)\end{array}$ & $\begin{array}{l}2.79 \\
(2.06)\end{array}$ & $\begin{array}{l}0.169 \\
(0.075)\end{array}$ & $\begin{array}{l}0.035 \\
(0.041)\end{array}$ & $\begin{array}{l}0.006 \\
(0.003)\end{array}$ & $\begin{array}{l}47.88 \\
(12.58)\end{array}$ \\
\hline Xu River & $\begin{array}{l}7.63 \\
(0.42)\end{array}$ & $\begin{array}{l}16.83 \\
(8.15)\end{array}$ & $\begin{array}{l}7.53 \\
(2.89)\end{array}$ & $\begin{array}{l}4.33 \\
(1.55)\end{array}$ & $\begin{array}{l}2.25 \\
(1.23)\end{array}$ & $\begin{array}{l}0.72 \\
(1.18)\end{array}$ & $\begin{array}{l}1.71 \\
(1.41)\end{array}$ & $\begin{array}{l}0.115 \\
(0.070)\end{array}$ & $\begin{array}{l}0.046 \\
(0.068)\end{array}$ & $\begin{array}{l}0.004 \\
(0.004)\end{array}$ & $\begin{array}{l}43.38 \\
(9.69)\end{array}$ \\
\hline Muguang River & $\begin{array}{l}7.52 \\
(0.46)\end{array}$ & $\begin{array}{l}21.47 \\
(5.34)\end{array}$ & $\begin{array}{l}6.24 \\
(2.47)\end{array}$ & $\begin{array}{l}5.40 \\
(1.48)\end{array}$ & $\begin{array}{l}4.11 \\
(1.75)\end{array}$ & $\begin{array}{l}0.91 \\
(0.97)\end{array}$ & $\begin{array}{l}2.90 \\
(2.06)\end{array}$ & $\begin{array}{l}0.161 \\
(0.094)\end{array}$ & $\begin{array}{l}0.032 \\
(0.040)\end{array}$ & $\begin{array}{l}0.001 \\
(0.001)\end{array}$ & $\begin{array}{l}47.08 \\
(12.59)\end{array}$ \\
\hline Xuguang River & $\begin{array}{l}7.65 \\
(0.34)\end{array}$ & $\begin{array}{l}19.58 \\
(6.04)\end{array}$ & $\begin{array}{l}7.86 \\
(2.51)\end{array}$ & $\begin{array}{l}4.08 \\
(1.07)\end{array}$ & $\begin{array}{l}2.78 \\
(1.02)\end{array}$ & $\begin{array}{l}0.58 \\
(0.93)\end{array}$ & $\begin{array}{l}1.91 \\
(1.48)\end{array}$ & $\begin{array}{l}0.081 \\
(0.042)\end{array}$ & $\begin{array}{l}0.031 \\
(0.048)\end{array}$ & $\begin{array}{l}0.003 \\
(0.002)\end{array}$ & $\begin{array}{l}41.91 \\
(9.77)\end{array}$ \\
\hline Wangyu River & $\begin{array}{l}7.53 \\
(0.59)\end{array}$ & $\begin{array}{l}24.76 \\
(8.54)\end{array}$ & $\begin{array}{l}7.12 \\
(1.86)\end{array}$ & $\begin{array}{l}4.58 \\
(1.41)\end{array}$ & $\begin{array}{l}3.33 \\
(1.23)\end{array}$ & $\begin{array}{l}1.39 \\
(0.87)\end{array}$ & $\begin{array}{l}2.53 \\
(1.08)\end{array}$ & $\begin{array}{l}0.114 \\
(0.034)\end{array}$ & $\begin{array}{l}0.106 \\
(0.189)\end{array}$ & $\begin{array}{l}0.002 \\
(0.001)\end{array}$ & $\begin{array}{l}46.94 \\
(8.38)\end{array}$ \\
\hline
\end{tabular}


concentrations of TN $(8.82 \mathrm{mg} / \mathrm{L}), \mathrm{NH}_{4}-\mathrm{N}(5.30 \mathrm{mg} / \mathrm{L})$ and TP $(0.311 \mathrm{mg} / \mathrm{L})$. This suggests that measures of nutrient abatement from domestic wastewater are strongly needed to recover the water quality of this river considering that it receives large amounts of wastewater from households every year (Zheng et al., 2001). The Zhihu River, Wujin River, Xiaoxi River and Shedu River showed relatively high $\mathrm{TN}$ and $\mathrm{NH}_{4}-\mathrm{N}$ contents; while the Wujin River and Taige Canal showed higher TP concentrations than the others except for the Liangxi River. Though diffuse pollution contributed more than $60 \%$ nutrient $(\mathrm{N}, \mathrm{P})$ loading (Wang et al., 2004), high concentrations of nutrients and phosphorus were found in rivers strongly affected by urbanization (i.e. Liangxi River, Zhihu River, Wujin River, Xiaoxi River and Taige Canal), which was the main reason for the hypertrophic state of the northern part of Taihu Lake (Chen et al., 2003). This suggests that it is urgent to control point pollutions in the Taihu watershed. In contrast, the Taipu River presented the lowest values of $\mathrm{TN}(0.54 \mathrm{mg} / \mathrm{L}), \mathrm{NH}_{4}-\mathrm{N}(0.23 \mathrm{mg} / \mathrm{L})$ and $\mathrm{TP}(0.055$ $\mathrm{mg} / \mathrm{L})$. The Caoqiao River and Wujin River showed the highest concentrations of Petro, with values of 0.812 and $0.716 \mathrm{mg} / \mathrm{L}$, respectively. Petroleum in rivers of the Taihu watershed mainly comes from ships (Cai et al., 1997). This suggests there exists heavy leaking of petroleum from ships on the two rivers. The highest value of V-phen $(0.069 \mathrm{mg} / \mathrm{L})$ was found in the Taige Canal, while smaller amounts of $\mathrm{V}$-phen were found in other rivers, with values ranging from $0.001-0.019 \mathrm{mg} / \mathrm{L}$.

\subsection{Principal component analysis on parameters of wa- ter quality in rivers}

Multivariate statistical approaches, such as PCA and $\mathrm{CA}$, were widely and comprehensively used to identify significant parameters for the characterization of the systems or similarity of environmental areas (Maria and Graca, 2006). PCA was performed here to identify characteristics of water quality variables in all studied rivers, based on the data set obtained from monthly monitoring during the study period. The factor loading matrix is listed in Table 3, and a planar plot of the eleven variables against their values for axes $\mathrm{X}$ and $\mathrm{Y}$ is shown in Fig.2. It can be seen that three significant factors (i.e., eigenvalue $>1$ ) were extracted by PCA, which explains $69 \%$ of the total variation. The first

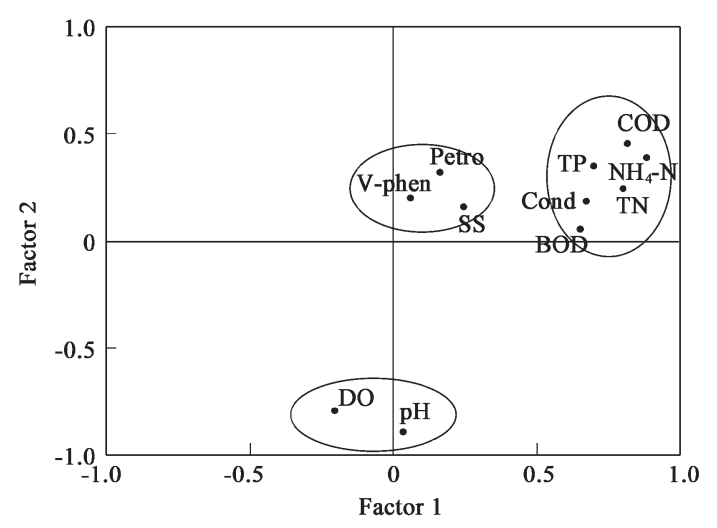

Fig. 2 Principal component analysis for water quality parameters.
Table 3 Rotated component matrix

\begin{tabular}{llll}
\hline Variable & PC1 $(39 \%)$ & PC2 $(16 \%)$ & PC3 $(14 \%)$ \\
\hline COD & 0.807 & -0.183 & 0.175 \\
BOD & 0.595 & 0.067 & 0.339 \\
$\mathrm{NH}_{4}-\mathrm{N}$ & 0.869 & -0.096 & -0.052 \\
$\mathrm{TN}$ & 0.816 & -0.092 & -0.019 \\
$\mathrm{TP}$ & 0.668 & -0.197 & 0.061 \\
Petro & 0.301 & -0.215 & 0.613 \\
V-phen & 0.018 & -0.246 & 0.563 \\
pH & 0.013 & 0.882 & -0.145 \\
$\mathrm{SS}$ & 0.276 & -0.091 & 0.551 \\
DO & -0.254 & 0.673 & 0.020 \\
Cond & 0.704 & -0.016 & 0.099 \\
\hline
\end{tabular}

factor (PC1) accounts for $39 \%$ of the total variance and captures all nutrient related variables $\left(\mathrm{TN}, \mathrm{NH}_{4}-\mathrm{N}, \mathrm{COD}\right.$, BOD, TP and conductivity). The second factor (PC2) accounts for $16 \%$ of the total variance and is significantly related to $\mathrm{pH}$ and DO. Meanwhile, Petro, V-phen and SS accounted for the greatest loading for Factor 3 (PC3), which explains $14 \%$ of the total variation. By using PCA, the 11 original variables were reduced to 3 key independent factors. Each factor that is significantly related to specific variables represents a different dimension of the water quality. The first factor represents the nutrient dimension, which is related to all nutrient variables. The high correlation of nutrient variables suggests that there is high consistency in their variations, which is in agreement with previous research conducted on Taihu Lake (Cai et al., 1997; Yao et al., 2005). Furthermore, this factor accounts for the majority of total variance, which suggests that overloading of nutrients is the principal environmental problem to aquatic systems in the Taihu watershed (Luo et al., 2005). The second factor may be taken as an ecological response dimension (feedback effects), considering that $\mathrm{pH}$ and DO are strongly influenced by other environmental variables, and the two indicators are sensitive to water pollution (Boyle and Fraleigh, 2003; Bellos et al., 2004). The third factor denotes the organic chemical contamination dimension because of the dominant contribution from Petro and V-phen to this factor.

\subsection{Classification of rivers based on factors of water quality}

CA has been proved useful in solving classification problems where the object is to sort cases or variables into groups, such that the degree of association is strong between members of the same cluster and weak between members of different clusters (Maria and Graca, 2006). To examine anthropogenic influences on the distribution of water quality in the 19 studied rivers, multivariate cluster analysis was applied to classify these rivers based on each significant factor obtained by PCA. Three dendrograms produced by multivariate cluster analysis for these factors are shown in Figs.3, 4, and 5, respectively.

\subsubsection{First factor}

For Factor 1 (nutrient factor), the 19 rivers were divided into 3 groups by multivariate cluster analysis (Fig.3). The average values of variables significantly related to Factor 1 
are presented for each group in Table 4. Group 1 includes 9 rivers mainly influenced by agricultural runoff and shows the lowest contents for related water indicators, especially for COD, BOD, TN, $\mathrm{NH}_{4}-\mathrm{N}$ and TP, compared with other groups. This indicates that agriculture puts less stress on water quality in river systems, despite the large nutrient output from agricultural systems in the Taihu region. Group 2, which consists of 4 rivers (South-Taige Canal, Shedu River, Wusong River and Sudong River) that are highly influenced by household or aquaculture, showed relatively higher nutrient concentrations than Group 1. This supports the view that aquaculture is one of the main reasons for the deterioration of water quality (Zheng et al., 2001). Group 3 consists of the rest 6 rivers and was characterized by the highest concentrations of COD, BOD, $\mathrm{TP}, \mathrm{TN}, \mathrm{NH}_{4}-\mathrm{N}$ and conductivity. As most of these rivers are in the close vicinity of the metropolis, rapid urbanization must be the principal reason for the deterioration of water quality in these rivers, and furthermore acceleration of eutrophication in the adjacent part of Taihu Lake (Li et al, 2001; Chen et al., 2003).

\subsubsection{Second factor}

Based on the second factor dataset ( $\mathrm{pH}$ and DO subset), all 19 rivers were also classified into 3 groups (Fig.4). Table 5 shows the average values of variables that are significantly related to this factor ( $\mathrm{pH}$ and $\mathrm{DO}$ ) for each classified group. Group 1 includes all the rivers strongly influenced by sewage from industry and households and

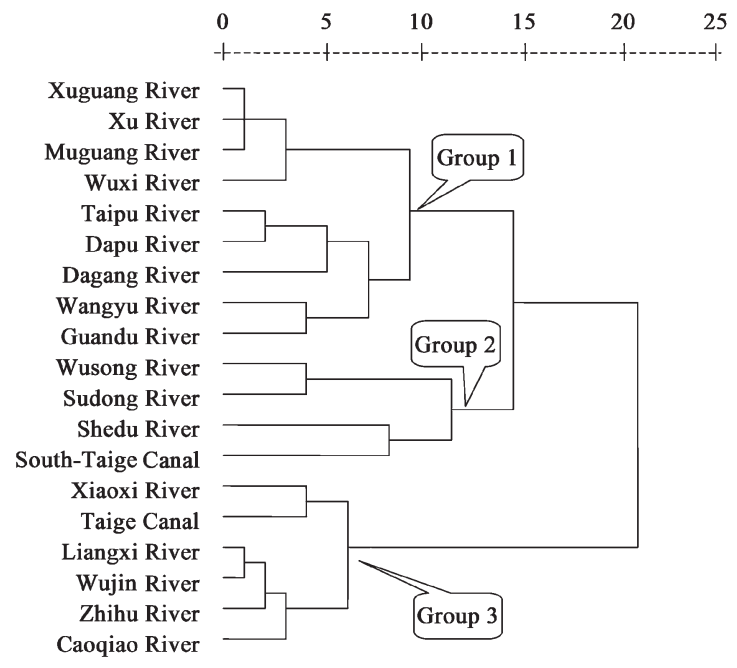

Fig. 3 Dendrogram of Q-hierarchical cluster analysis for Factor 1 dataset (nutrient related variables subset).

Table 4 Average values of the indicators related to Factor 1 for the three groups computed by hierarchical cluster analysis

\begin{tabular}{llll}
\hline & Group 1 & Group 2 & Group 3 \\
\hline COD $(\mathrm{mg} / \mathrm{L})$ & $4.48(2.85)^{\mathrm{a}}$ & $6.06(3.41)$ & $7.37(3.16)$ \\
$\mathrm{BOD}(\mathrm{mg} / \mathrm{L})$ & $3.87(2.06)$ & $5.57(3.78)$ & $6.51(2.29)$ \\
$\mathrm{TN}(\mathrm{mg} / \mathrm{L})$ & $2.67(1.22)$ & $3.76(2.13)$ & $5.54(1.59)$ \\
$\mathrm{NH}_{4}-\mathrm{N}(\mathrm{mg} / \mathrm{L})$ & $0.89(0.58)$ & $2.33(1.48)$ & $3.86(1.38)$ \\
$\mathrm{TP}(\mathrm{mg} / \mathrm{L})$ & $0.105(0.034)$ & $0.189(0.098)$ & $0.264(0.138)$ \\
Cond $(\mu \mathrm{S} / \mathrm{cm})$ & $42.56(16.62)$ & $53.56(24.03)$ & $66.75(15.63)$ \\
\hline
\end{tabular}

${ }^{\mathrm{a} B r a c k e t}$ values are S.D.; the same for the following tables.

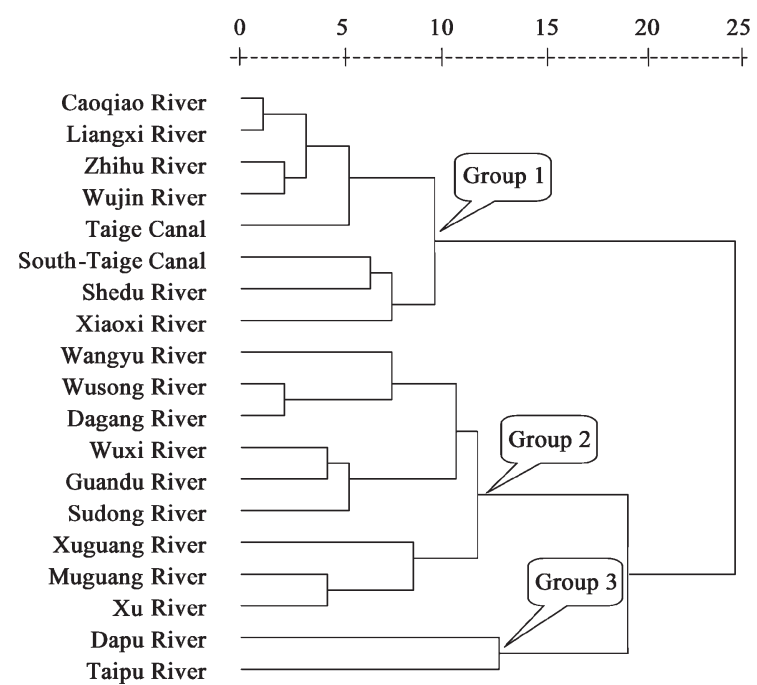

Fig. 4 Dendrogram of Q-hierarchical cluster analysis for Factor 2 dataset (pH and DO subset).

Table 5 Average values of the indicators related to Factor 2 for the three groups computed by hierarchical cluster analysis

\begin{tabular}{llll}
\hline & Group 1 & Group 2 & Group 3 \\
\hline $\mathrm{pH}$ & $7.43(3.97)$ & $7.36(2.19)$ & $7.65(1.18)$ \\
$\mathrm{DO}(\mathrm{mg} / \mathrm{L})$ & $3.56(1.88)$ & $5.98(2.68)$ & $9.06(3.57)$ \\
\hline
\end{tabular}

presented the lowest values of $\mathrm{pH}$ (7.43) and DO (3.56 $\mathrm{mg} / \mathrm{L})$. This illustrates a serious negative feedback of pollution in these rivers in view of the fact that low levels of $\mathrm{pH}$ and DO decrease the diversity of fauna and flora in aquatic systems (Azrina et al., 2006). Group 2 is composed of 10 rivers affected by agriculture or aquaculture, with average values of $\mathrm{pH}$ and DO being 7.36 and $5.98 \mathrm{mg} / \mathrm{L}$, respectively. However, Group 3, which yielded the highest average values of $\mathrm{pH}(7.65)$ and DO $(9.06 \mathrm{mg} / \mathrm{L})$, consists of the Dapu River and Taipu River. These two rivers mainly flow through hill country, where less fertilizer is used in agriculture systems. This might explain why these two rivers have the highest DO content (Wang et al., 2004).

\subsubsection{Third factor}

A plot of cluster analysis based on the third factor dataset (Petro, V-phen and SS subset) is presented in Fig.5, and the average values of related variables are listed in Table 6. Four groups were produced among the 19 rivers by CA. Rivers influenced by agriculture or aquaculture are in Group 1, with the lowest contents of Petro (0.094 $\mathrm{mg} / \mathrm{L}), \mathrm{V}$-phen $(0.006 \mathrm{mg} / \mathrm{L})$ and SS $(28.17 \mathrm{mg} / \mathrm{L})$ (Table $6)$. Group 2, however, consists of only the Taige Channel and had the highest concentrations of V-phen $(0.069$ $\mathrm{mg} / \mathrm{L})$. It indicated an extraordinary concentrative pattern of V-phen pollution distribution. Group 3 consists of the Liangxi River, Zhihu River and Xiaoxi River and yielded a relatively high content of Petro. Group 4 was composed of the Wujin River and Caoqiao River and presented the highest values of Petro $(0.764 \mathrm{mg} / \mathrm{L})$ and SS $(68.72 \mathrm{mg} / \mathrm{L})$. This indicates localization in the distribution pattern of Petro pollution, coinciding with that of V-phen. It suggests the distributions of organic compound pollutions, such as 


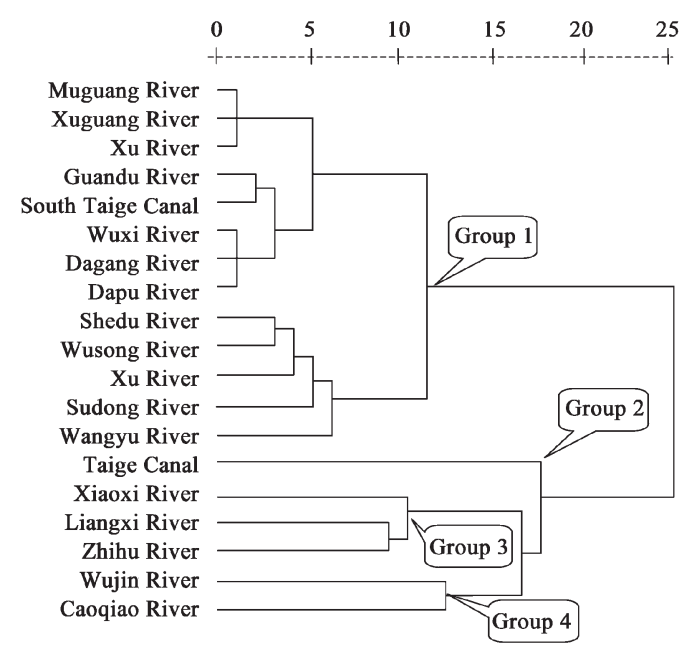

Fig. 5 Dendrogram of Q-hierarchical cluster analysis for Factor 3 dataset (Petroleum s, V-phen and SS subset).

Table 6 Average values of the indicators related to Factor 3 for the four groups computed by hierarchical cluster analysis

\begin{tabular}{lllll}
\hline & Group 1 & Group 2 & Group 3 & Group 4 \\
\hline Petro $(\mathrm{mg} / \mathrm{L})$ & 0.094 & 0.289 & 0.331 & 0.764 \\
& $(0.056)$ & $(0.069)$ & $(0.097)$ & $(0.162)$ \\
V-phen $(\mathrm{mg} / \mathrm{L})$ & 0.006 & 0.069 & 0.009 & 0.013 \\
& $(0.004)$ & $(0.045)$ & $(0.004)$ & $(0.008)$ \\
SS $(\mathrm{mg} / \mathrm{L})$ & 28.17 & 58.97 & 51.52 & 68.72 \\
& $(10.46)$ & $(34.15)$ & $(10.15)$ & $(1.46)$ \\
\hline
\end{tabular}

Petro and V-phen, are focused on areas strongly influenced by sewage from industry and ships.

\section{Conclusions}

In this study, the variables of water quality in rivers around Taihu Lake were identified by factor analysis and grouped into three independent key factors, i.e. a nutrient factor (relating all nutrient variables), a feedback factor (relating $\mathrm{pH}$ and DO), and an organic chemical pollution (related to Petroleum and V-phen). Hierarchical cluster analysis grouped the 19 studied rivers into three or four clusters with similar characteristics based on each factor obtained by PAC. The results suggest that anthropogenic activities have had significant effects on water quality in the rivers. The rivers strongly influenced by household wastewater presented the highest concentrations of nutrients (TN and TP). However, agriculture was proved to put less pressure on the nutrient concentrations in adjacent rivers. Rivers in the vicinity of cities presented serious negative feedback of water pollution, considering their low DO level. Rivers flowing through the countryside, especially through hilly areas, were found to have high DO content. Two rivers influenced by sewage from industry and ships were distinguished from others with high values of Petroleum. The Taige Channel, located in Changzhou City, was characterized by an extremely high value of $\mathrm{V}$-phen due to discharge of wastewater from industry. However, rivers mainly influenced by agriculture or aquaculture were identified as being less organic-chemical pollutant. This study clarifies anthropogenic influences on river water quality. Thus, it provides better information about factors that affect water quality and improves the design of the monitor network for effective management of water sources.

\section{References}

Azrina M Z, Yap C K, Ismail A R et al., 2006. Anthropogenic impacts on the distribution and biodiversity of benthic macroinvertebrates and water quality of the Langat River, Peninsular Malaysia[J]. Ecotoxicology and Environmental Safety, 64: 337-347.

Bellos D, Sawidis T, Tsekos I, 2004. Chemical pollution monitoring of river Pinios (the ssalia-Greece)[J]. Environ Int, 30: $105-115$.

Bernard P, Antoine L, Bernard L, 2004. Principal component analysis: an appropriate tool for water quality evaluation and management-application to a tropical lake system[J]. Ecol Model, 178: 295-311.

Boyle T P, Fraleigh H D, 2003. Natural and anthropogenic factors affecting the structure of the structure of the benthic macroinvertebrate community in an effluent-dominated reach of the Santa Cruz River, AZ[J]. Ecol Ind, 3: 93-117.

Cai Q M, Gao X Y, Xu W et al., 1997. Dynamic variations of water quality in Taihu Lake and multivariate analysis of its influential factors[J]. J Chinese Geogr, 7: 97-106.

Chen J C, Heinke G W, Zhou M J, 2004. The Pearl River pollution project (PREPP)[J]. Continental Shelf Research, 24: 17391744.

Chen W, Chen Y X, Gao I, 1997. Eutrophication of Taihu and its control[J]. Agri Engin, 6: 109-120.

Chen Y W, Fan C X, Katrin T et al., 2003. Changes of nutrients and phytoplankton chlorophyll- $a$ in a large shallow lake, Taihu, China: an 8-year investigation[J]. Hydrobiologia, 506: 273-279.

Gibert C S, Wendy A T, 2003. Watershed scale assessment of nitrogen and phosphorus loadings in the Indian River Lagoon Basin, Florida[J]. Environmental Management, 67: 363-372.

Jin X C, 1998. Criterion of eutrophiction survey on Lakes[M]. Beijing: Environmental Science Press.

Jin X C, 2000. Control technology of eutrophical lake in China[G]. Specialist dissertation of international learning workshop about eutrophical lake and its control technology in China. Dali China, 10: 215-223.

Kunwar P S, Amrita M, Sarita S, 2005. Water quality assessment and apportionment of pollution sources of Gomti River (India) using multivariate statistical techniques-a case study[J]. Analytica Chimica Acta, 538: 355-374.

Lau S S S, Lane S N, 2002. Biological and chemical factors influencing shallow lake eutrophication: a long-term study[J]. Sci Total Environ, 228: 167-181.

Li R G, Xia Y L, Wu A Z, 2000. Pollutants sources and their discharging amount in Taihu Lake area of Jiangsu Province[J]. Lake Sci China, 12: 147-153.

Lin H Y, Han W Y, 2001. Water quality assessment and analysis before and after the decade of the dry period in Lingdingyang Estuary of the Pearl River Mouth[J]. Marine Environmental Science, 20: 28-31.

Liu L, 2005. Research of measure methods of petroleum-like matters in industrial waste water[J]. Metallurgical Power, 
111: 60-62.

Ludwig J A, Reynolds J F, 1988. Statistical ecology[M]. New York: J. Wiley and Sons.

Luo J, Pang Y, 2005. Study on flux of pollutants discharged into Taihu Lake through main inflow river channels[J]. Hohai University, 33: 131-135.

Maria J B, Graca C, 2006. Identification of similar environmental areas in Tagus Estuary by using multivariate analysis[J]. Eco Ind, 6: 508-515.

May A M, Mutasem E, Mark D S et al., 2006. Factors influencing development of management strategies for the Abou Ali River in Lebanon[J]. Sci Total Environ, 362: 15-30.

Reyment R, Joreskog K G, 1993. Applied factor analysis in the natural sciences[M]. Cambridge: Cambridge University Press.
Wang X J, Zhang W, Huang Y N et al., 2004. Modeling and simulation of point-non-point source effluent trading in Taihu Lake area: Perspective of non-point sources control in China[J]. Sci Total Environ, 325: 39-50.

Yao H M, Huang R T, Liu Y et al., 2005. Principal component analysis of the water high entrophication evaluation in Taihu Lake[J]. Guiling University of Technology, 25: 248251.

Yu S, Shang J, 2003. Factor analysis and dynamics of water quality of the Songhua River, Northeast China[J]. Water Air Soil Pollut: 144, 159-169.

Zheng Y, Wang X J, Jiang Y C et al., 2001. Analysis on water quality of rivers around Tai Lake and estimation of total pollutant load into Tai Lake[J]. Geography and Territorial Research, 17(1): 40-44. 